\title{
Tropical dendrochronology applied to invasive tree species in the Brazilian Atlantic Forest
}

\author{
Carolina Nogueira Xavier ${ }^{1}$ Daniela Granato-Souza ${ }^{1,2}$. \\ Ana Carolina M. C. Barbosa ${ }^{1}$. \\ José Reinaldo Moreira da Silva ${ }^{1}$
}

Received: 5 August 2019 / Accepted: 24 October 2019 / Published online: 13 December 2019

(C) The Author(s) 2019

\begin{abstract}
The Atlantic Forest is one of the largest and most biodiverse rainforests of South America but anthropogenic activities are drastically changing these landscapes. The invasion of alien or exotic species is one of the greatest threats to biodiversity. There are few studies of invasive species in tropical Brazilian ecosystems. This research examines growth and ecological aspects of Syzygium cumini and Clitoria fairchildiana, two invasive tree species in the Pedra Branca State Park, an Atlantic Forest remnant in southeastern Brazil. Both species were successfully dated, indicating an average age of 58 and 31 years, respectively. A positive relationship between growth and precipitation of the previous growing season suggests an ecological adaptive strategy, which could be facilitating their invasion into the environment. Cumulative growth diameter curves indicate slow and fast growth rates for S. cumini and C. fairchildiana, respectively. Growth release episodes detected in the tree rings indicate increased anthropogenic disturbances over the last 50 years.
\end{abstract}

Project funding: The work was partially supported by CAPES (Coordenação de Aperfeiçoamento de Pessoal de Nível SuperiorBrasil-Finance Code 001).

The online version is available at http://www.springerlink.com

Corresponding editor: Tao Xu.

Daniela Granato-Souza danigsbio@gmail.com

1 Forest Sciences Department, Federal University of Lavras (UFLA), C.P. 3037, Lavras 37200-000, Brazil

2 Department of Geosciences, University of Arkansas, Fayetteville, AR 72701, USA
Keywords Atlantic Forest biome - Invasive species · Protected areas · Tree rings

\section{Introduction}

The Atlantic Forest is one of the largest rainforests of South America, widespread over tropical to subtropical regions and ranging from sea level to $\sim 3000 \mathrm{~m}$ with high biodiversity. It is considered one of the 25 world hotspots (Myers et al. 2000; Tabarelli et al. 2005; Forzza et al. 2012). In Brazil, most of the Atlantic Forest region also includes some densely populated cities and human disturbances have drastically changed natural landscapes. This has resulted in significant habitat losses over past decades (Myers et al. 2000; Tabarelli et al. 2005; Zenni and Ziller 2011).

The introduction of non-native species may be one of the greatest threats to native urban environments (Gaertner et al. 2017), affecting ecological balance and biodiversity. The first records of exotic species in Brazil date from the early eighteenth century in the southeast (Zenni and Ziller 2011). Intentional or accidental introductions characterize patterns of the invasions but cultural and economic reasons are also important in an urban context (Zenni and Ziller 2011). However, little is known of the ecological aspects of these exotics, and strategies to prevent or reduce invasiveness do not exist or are ineffective (Zenni and Ziller 2011; Gaertner et al. 2017).

Understanding the mechanisms of biological introductions is challenging and a priority for the restoration of disturbed environments (Tabarelli et al. 2005). Dendrochronology is based on the study of tree ring formation (Fritts 1976; Stokes and Smiley 1996) and has provided reliable age-related information on tropical tree species (Stahle et al. 1999; Brienen and Zuidema 2005; Schöngart et al. 2015). 
Based on dendrochronological research, non-native or exotic tree species with distinct growth rings can be analyzed (Closset-Kopp et al. 2011; Nuñez and Paritsis 2018; Brandes et al. 2019; Nogueira et al. 2019). Recent research has shown that the analysis of tree rings may also be applied to understanding growth patterns of non-native species, providing useful information on the introduction, invasiveness, and spatial-temporal distribution, although mainly in temperate environments (Closset-Kopp et al. 2011; Kasson et al. 2013; Nuñez and Paritsis 2018). However, there are few studies with similar approaches in Brazilian tropical environments (Brandes et al. 2019; Nogueira et al. 2019), which mainly concentrated in the development of chronologies with native species (Callado et al. 2001; Fontana et al. 2018; Lisi et al. 2008; Aragão et al. 2019). Hence, a study of the growth trajectories of invasive species could contribute to understanding what benefits their establishment in new environments.

Conservation strategies have been applied to Atlantic Forest remnants, with most efforts towards the creation of "protected areas", that includes parks, reserves, ecological stations and private reserves, and are strictly regulated by Brazilian environmental agencies (Tabarelli et al. 2005). The Pedra Branca State Park is one of the largest urban forests in the world. It is rich in biodiversity and plays an important role in the hydrological cycle of Rio de Janeiro. A list of alien species has been described for Pedra Branca State Park and surrounding area and identified an unusually large presence of three non-native tree species: Artocarpus heterophyllus Lam (Moraceae), Syzygium cumini (L.) Skeels (Myrtaceae) and Clitoria fairchildiana R.A.Howard (Fabaceae) (Zenni and Ziller 2011; Fiotec 2016).

Therefore, the goals of this study are to determine if these three species show distinct annual tree rings that can be reliably cross-dated, and the potential of the resulting chronologies to assess tree ages, reconstruct their growth trajectories and detect growth releases that could be related to past disturbances in the forest fragment. The climate-growth relationship of these species is also determined.

\section{Materials and methods}

\section{Study site}

The Pedra Branca State Park is located in the Rio de Janeiro municipality, southeastern Brazil (22 $56^{\prime} 12^{\prime \prime} \mathrm{S} ; 43^{\circ} 24^{\prime} 12^{\prime \prime}$ $\mathrm{W}$; Fig. 1), and is considered one of the most representative in area and biodiverse urban parks of the world. It is Brazil's largest urban forest, covering approximately 12,400 ha (INEA 2015). It was declared a protected area by the State Government of Rio de Janeiro in 1974 and has been managed by the Fundação Oswaldo Cruz since 2007, which has its own campus of approximately 500 ha in the Park's buffer zone (Fiocruz 2009). This remnant of the Atlantic Forest plays a key role in controlling the water balance of the city of Rio de Janeiro, covering $10 \%$ of its territory. The city
Fig. 1 a Map showing the remaining Atlantic Forest biome distribution (shaded area) and the study site (red dot); b Pedra Branca State Park and surrounding buffer zone delimited by red line, and the study area by white dot. c Distribution of sampled A. heterophyllus (white dots), C. fairchildiana (blue dots) and S. cumini (red dots) within the buffer zone; d Climate diagram of Pedra Branca State Park. Data source: CRU TS4.00 0.5 gridded data set from 1956 to $2018,16^{\circ}-24^{\circ} \mathrm{S}, 40^{\circ}-50^{\circ} \mathrm{W}$

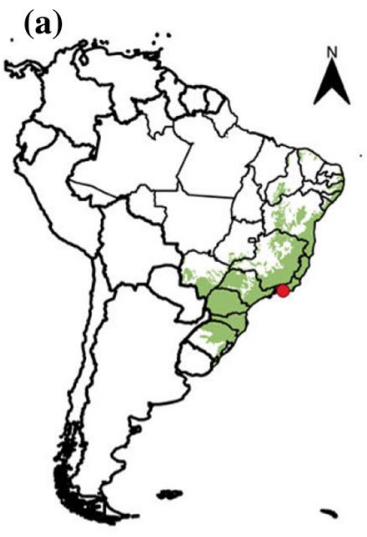

(b)

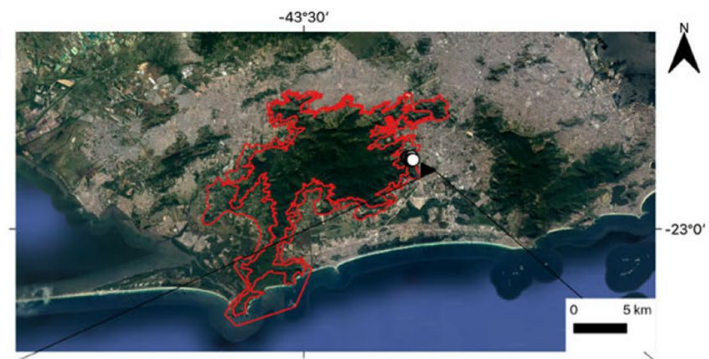

(c)

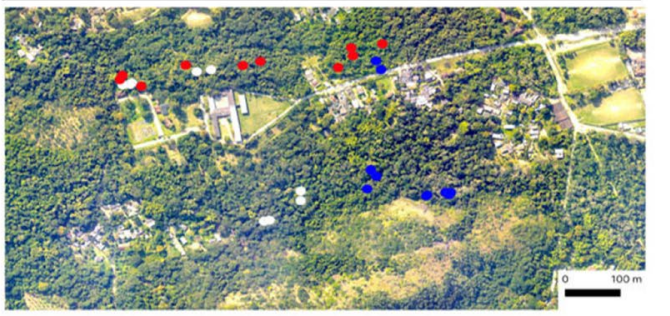

(d)

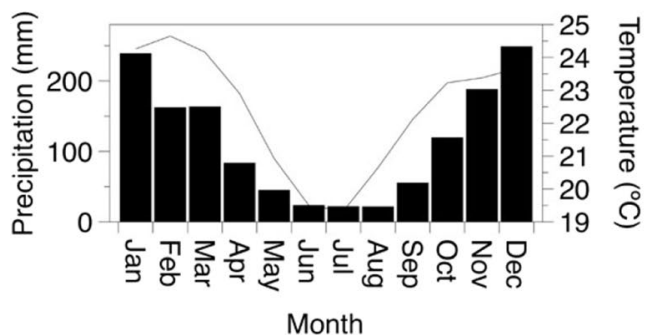


is responsible for maintaining 50\% of the Atlantic Forest remnants within its area (INEA 2015). Historical occupation has resulted in anthropogenic disturbances of the natural environment over many years, including the introduction of invasive species (Drummond 1997; Costa 2002).

According to the Köppen climate classification, the region is humid tropical, with humid summers extending from December to March (average rainfall $800 \mathrm{~mm}$ ), and the driest season during the winter months of June-August (average rainfall $60 \mathrm{~mm}$ ) (Fig. 1d). The average annual precipitation is $1300 \mathrm{~mm}$, and there is little variation over the average temperature of $22{ }^{\circ} \mathrm{C}$. All the climate data were obtained from CRU TS4.01, $16^{\circ}-24^{\circ} \mathrm{S}$ and $50^{\circ}-40^{\circ} \mathrm{W}$ from 1956 to 2018.

\section{Target species}

Artocarpus heterophyllus (Jackfruit) is native to southeastern Asia (Chaves et al. 1967; Ferrão 1993). It is an evergreen, monoecious species, attaining heights of more than $10 \mathrm{~m}$ (Chaves et al. 1967; Crane et al. 2002; Fig. 2a). Flowering usually occurs between October and January (Barbosa 2016) with continuous fruiting over the year, but preferably during the summer months of December-February in Brazil (Cunha et al. 2006). Records of the first introductions date to the end of the seventeenth century in northeastern Brazil (Dean 2002), and the species was widely used for ornamental purposes during the nineteenth century (Santos et al. 2008). The first records of the introduction of A. heterophyllus in the Rio de Janeiro municipality date back to 1862 in an attempt to recover areas degraded by cane and coffee production (Atala et al. 1966; Bandeira 1993; Dean 2002; Conti et al. 2008).

Syzigium cumini (Java plum) is a native, evergreen species of India and Sri Lanka, reaching heights of $20 \mathrm{~m}$, flowering between September and November (Lorenzi et al. 2003), and fruiting January to May (Vizzotto and Fetter 2009; Fig. 2b). Syzygium cumini has medicinal properties for treating hypoglycemia (low blood sugars), and with antiinflammatory and antioxidant properties, and hence has been used as alternative medicine by local people (Siani et al. 2000; Braga et al. 2007; Lima et al. 2007). Syzygium cumini usually have dense crowns and have been introduced into Brazilian environments for ornamental purposes (Lorenzi et al. 2003). Additionally, S. cumini are reported to grow in many soil types and produce polyembryonic fruit; such characteristics may have favored progressive invasion of different Brazilian environments (Gurgel and Soubihe Sobrinho 1951; Donadio 2007).

Clitoria fairchildiana (sombreiro) is a native of the Amazon forests and classified as a light-demanding, pioneer species, most common in secondary forests. It is deciduous, reaching heights of 6-12 m and usually colonizes open, disturbed forests (Lorenzi 1992; Fig. 2c). Flowering occurs during the boreal summer of April-May, with fruiting in May-July when it starts to shed leaves. It produces approximately 1800 seeds per year (Lorenzi 1992). A large canopy and fast growth rates have made $C$. fairchildiana a species widely applied to the recovery of degraded areas (Lorenzi 1992). However, C. fairchildiana is allelopathic and not ideal for introduction into its non-native environments (Soares et al. 2002; Sampaio and Schmidt 2014).

\section{Sampling}

Cross sections were obtained from legally felled trees of $S$. cumini, C. fairchildinana and A. heterophyllus in the Park's buffer zone (License no 002920 granted by the Secretaria Municipal de Ambiente e Cultura do Rio de Janeiro-SMAC). Thirty trees $>20 \mathrm{~cm}$ diameter at breast height $(\mathrm{DBH})$ were
Fig. 2 a Artocarpus heterophyllus, b Syzigium cumini and c Clitoria fairchildiana in the buffer zone
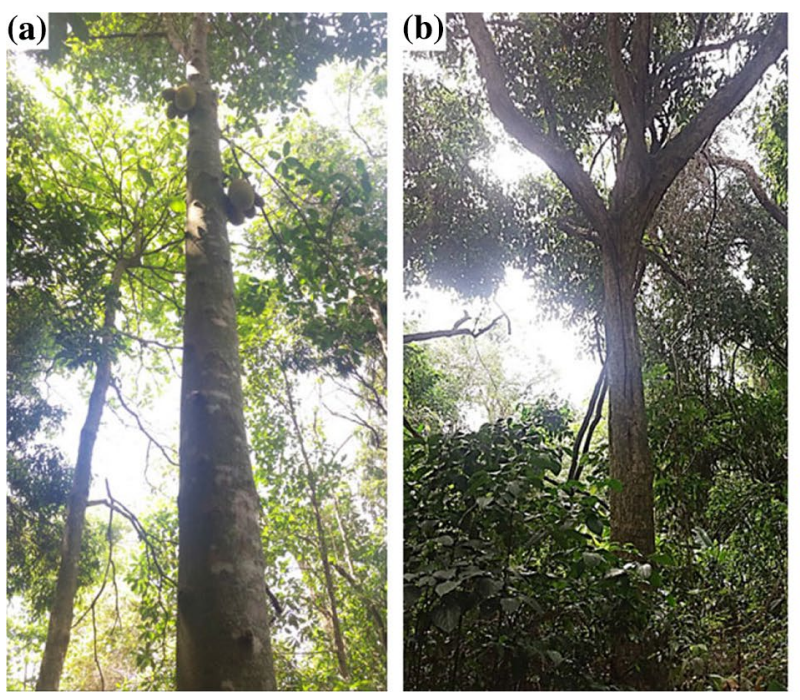
sampled, 10 trees per species. Cross sections were obtained from the base $(0.30 \mathrm{~cm}$ above ground) for tree-ring analyses. DBH and total height were measured for individual trees (Table 1).

\section{Tree-ring analyses}

Cross sections were dried and polished to obtain a clear surface and crossdating carried out using skeleton plots and visual dating under a microscope (Douglass 1941; Stokes and Smiley 1996). Growth ring boundaries of each species were identified and marked according to the recommendations of the International Association of Wood Anatomists (IAWA Committee 1989). At least one radius per specimen was marked and the dated ring widths measured to a precision of $0.001 \mathrm{~mm}$ (LINTABTSAPTM; Rinntech 2017). The resulting time series were submitted to dating and measurement quality control with the computer program COFECHA (Holmes 1983).

The time series were detrended and standardized by fitting cubic smoothing splines to remove non-climatic, low frequency growth trends using the program ARSTAN (Cook 1985; Cook and Krusic 2005). The detrending and standardization procedure removed low frequency variance from the relatively short ring width series, where lower frequency variance is more likely to result from age trends and stand dynamics. Tree ring indices were computed by dividing the measured ring width value for each year by the value of the fitted curve for the same year (ratios). The resulting indices of each radius from all trees were averaged on a year-by-year basis to construct the standard tree-ring chronology (Cook 1985; Cook and Krusic 2005).

A series of statistics were computed with the ARSTAN program to describe the internal consistency of the individual ring width series and the resulting standard chronology, [e.g., mean correlation among all series (RBAR; Cook and Pederson 2011), and the expressed population signal (EPS; Wigley et al. 1984)]. The quality of the chronology was evaluated by the value of RBAR, which is the average correlation coefficient resulting from comparing all possible segments of a predetermined length among all the series in the chronology (Briffa 1995). The EPS values provide evidence of the existence of common signals among trees in an infinitely replicated chronology (Wigley et al. 1984;

Mérian et al. 2013).

\section{Climate-growth relationship}

The derived chronologies were used to investigate the relationship between tree growth and climate. Precipitation and temperature data were obtained from the Climatic Research Unit (CRU) TS4.00 $0.5^{\circ}$ gridded data set (Harris et al. 2014), and a Pearson correlation analysis used with a 95\% significance level (Fritts 1976). The analysis was performed with the treeclim package (Zang and Biondi 2015) of R Core Team (2018), and total monthly precipitation from December of the previous growing season $(t-2)$ to June $(t)$ at the end of the current growing season were computed over 19 consecutive months to identify the strongest monthly or seasonal precipitation signal.

\section{Growth trajectories}

The dated ring widths were measured on at least two radii per tree and used to model DBH as a function of tree age. The resulting increments per year were obtained through the average value of the analyzed radii per tree to correct growth variations within the trunk, (e.g., pith eccentricity, anomalies related to distorted trunks). Averaged annual increment rates for each tree were then accumulated to form individual growth curves related to the measured DBH (Brienen and Zuidema 2007; Schöngart 2008).

The study of growth rings provides access to a record of the response of trees growing under natural or disturbed environments. Abrupt changes in annual growth rates over the years reveal disturbance events or periods and can be precisely dated to the calendar year. The running mean method was used to identify growth release episodes on tree ring data performed by the TRADER package in R (Altman et al. 2014). The radial growth averaging method (Nowacki and Abrams 1997) was applied to calculate growth releases on tree ring data. Radial growth averaging identifies the percentage in growth change (\% GC) by averaging radial growth over 5- and 10-year periods, for $C$. fairchildiana and S. cumini respectively, which were the only two species successfully dated in this study, including the target year (M1), and the average radial growth over the subsequent 10-year period, excluding the target year (M2) (Eq. 1).

$\% \mathrm{GC}=[(\mathrm{M} 2-\mathrm{M} 1) / \mathrm{M} 1] \times 100$
Table 1 Description of the growth features of the tree species in the buffer zone of Pedra Branca State Park. Mean \pm SD

\begin{tabular}{lllll}
\hline Species & $\mathrm{N}$ & $\mathrm{DBH}(\mathrm{cm})$ & $\begin{array}{l}\text { Commercial } \\
\text { height }(\mathrm{m})\end{array}$ & Reason of introduction \\
\hline Artocarpus heterophyllus & 10 & $28.3( \pm 3.9)$ & $6.7( \pm 1.6)$ & Recovery of degraded areas \\
Syzygium cumini & 10 & $34.6( \pm 6.1)$ & $4.0( \pm 0.6)$ & Ornamental and fruit \\
Clitoria fairchildiana & 10 & $30.6( \pm 6.5)$ & $4.4( \pm 1.0)$ & Recovery of degraded areas \\
\hline
\end{tabular}


The minimum threshold is identified as moderate release with $25 \%$ of growth change, and major releases with $50 \%$ of growth change (Nowacki and Abrams 1997; Altman et al. 2014).

\section{Results}

Average DBH and commercial heights of the ten sampled trees of each species, A. heterophyllus, $C$. fairchildiana and $S$. cumini are shown in Table 1. The cross section discs of $A$. heterophyllus, $C$ fairchildiana and $S$. cumini show distinct growth rings, however crossdating was only possible for the last two species by standard dendrochronological methods (Fig. 3). Tree rings are characterized by alternating fiber and parenchyma bands in both $C$. fairchildiana (Fig. 3b) and $S$. cumini (Fig. 3c), but are better identified at lower magnification in $C$. fairchildiana samples because of apparent discontinuity of true tree ring boundaries. Distinct growth rings were also detected in A. heterophyllus, characterized by thick-walled and radially flattened latewood fibers compared with thin-walled earlywood fibers (Fig. 3a). However, the rings are not regularly distributed over the samples, preventing crossdating by standard dendrochronological methods.

Cross sections of 10 trees of S. cumini and nine of $C$. fairchildiana showed satisfactory growth rings, allowing the samples to be cross synchronized and dated, and providing evidence of their yearly growth (Table 2). Syzygium cumini trees are older, up to 76 years with the youngest at 52 years. There is little variation around the average age of individuals. Clitoria fairchildiana trees are younger, with a maximum age of 47 and half the trees less than 30 years old.

Preliminary standard chronologies of $S$. cumini and $C$. fairchildiana were developed with $6 / 12$ and 7/14 trees/radii, respectively, showing good internal correlation between individual series (Fig. 4a, b). Both standard chronologies are positively correlated during the common time interval $(1970-2016, r=0.19)$. However, the correlation is higher considering 1970-2010 ( $r=0.34$ ) (Fig. 4c). The lagged $(t-1)$ total annual precipitation in the area is shown in Fig. $4 \mathrm{c}$.

The chronologies of $S$. cumini and C. fairchildiana show significant correlation with the CRU gridded precipitation data (Fig. 5). Syzygium cumini is positively correlated with February precipitation $(r=0.46 ; p<0.01)$ and May $(r=0.27$; $p<0.05$ ) from the previous growing season (Fig. 5a). Clitoria fairchildiana is positively correlated with January precipitation $(r=0.45 ; p<0.01)$ from the previous rainy season and negatively correlated with precipitation of November $(-0.28 ; p<0.05)$ and March $(-0.29 ; p<0.05)$ of the current growing season (Fig. 5b). There is no relationship between temperature and the growth of both species. Cumulative diameter growth curves of both species show different patterns, suggesting slower/faster growth rates for S. cumini and C. fairchildiana, respectively (Fig. 6). Average annual increments of $3.5 \mathrm{~mm} /$ year $( \pm 2.5 \mathrm{SD})$ were verified for S. cumini and $5.5 \mathrm{~mm} /$ year $( \pm 4.1 \mathrm{SD})$ for $C$. fairchildiana.

The radial growth averaging method shows disturbance events in $68 \%$ of the total trees of S. cumini and C. fairchildiana (Fig. 7). Eight $S$. cumini and five out of nine $C$. fairchildiana showed at least one release episode during
Fig. 3 Growth rings of a Artocarpus heterophyllus, b Clitoria fairchildiana and $\mathbf{c}$ Syzigium cumini. True growth rings (black bars) and the zone with indistinct growth ring boundaries (white arrows) $(\mathrm{scale}=1 \mathrm{~cm})$
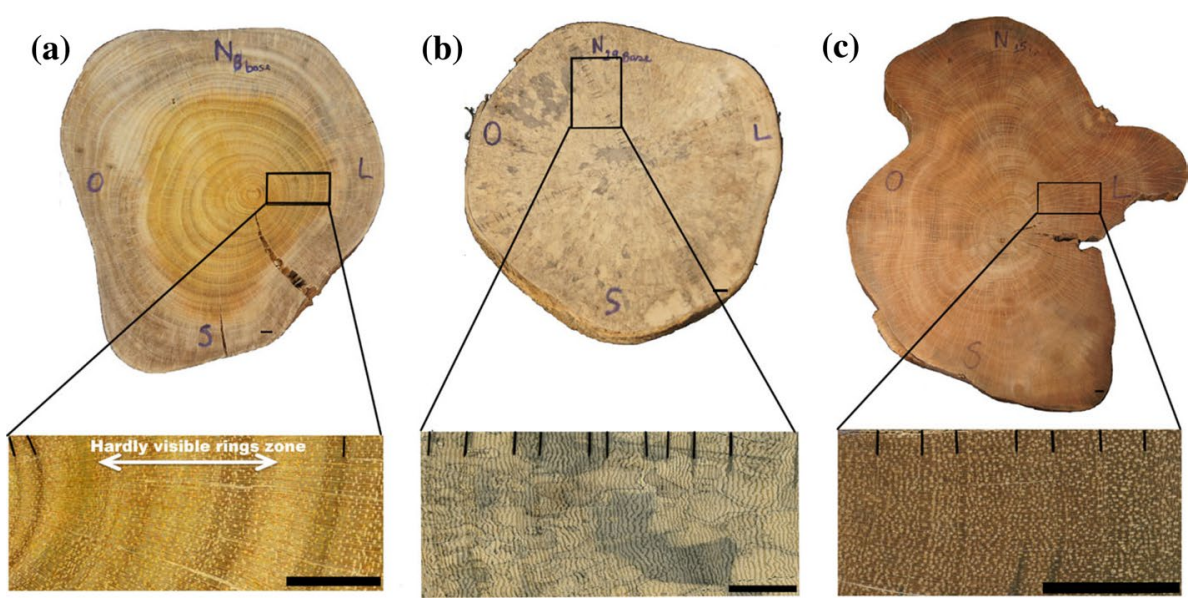

Table 2 Statistical parameters obtained with Cofecha software of S. cumini and $C$. fairchildiana chronologies

\begin{tabular}{llllllc}
\hline Species & Time span & Trees/Radii & Mean sensitivity & $\begin{array}{l}\text { Interseries } \\
\text { correlation }\end{array}$ & Mean age & Total dated rings \\
\hline S. cumini & $1941-2016$ & $10 / 18$ & 0.463 & 0.422 & $57.8 \pm 7.9$ & 1016 \\
C. fairchildiana & $1970-2016$ & $9 / 17$ & 0.515 & 0.425 & $31.1 \pm 12.4$ & 525 \\
\hline
\end{tabular}



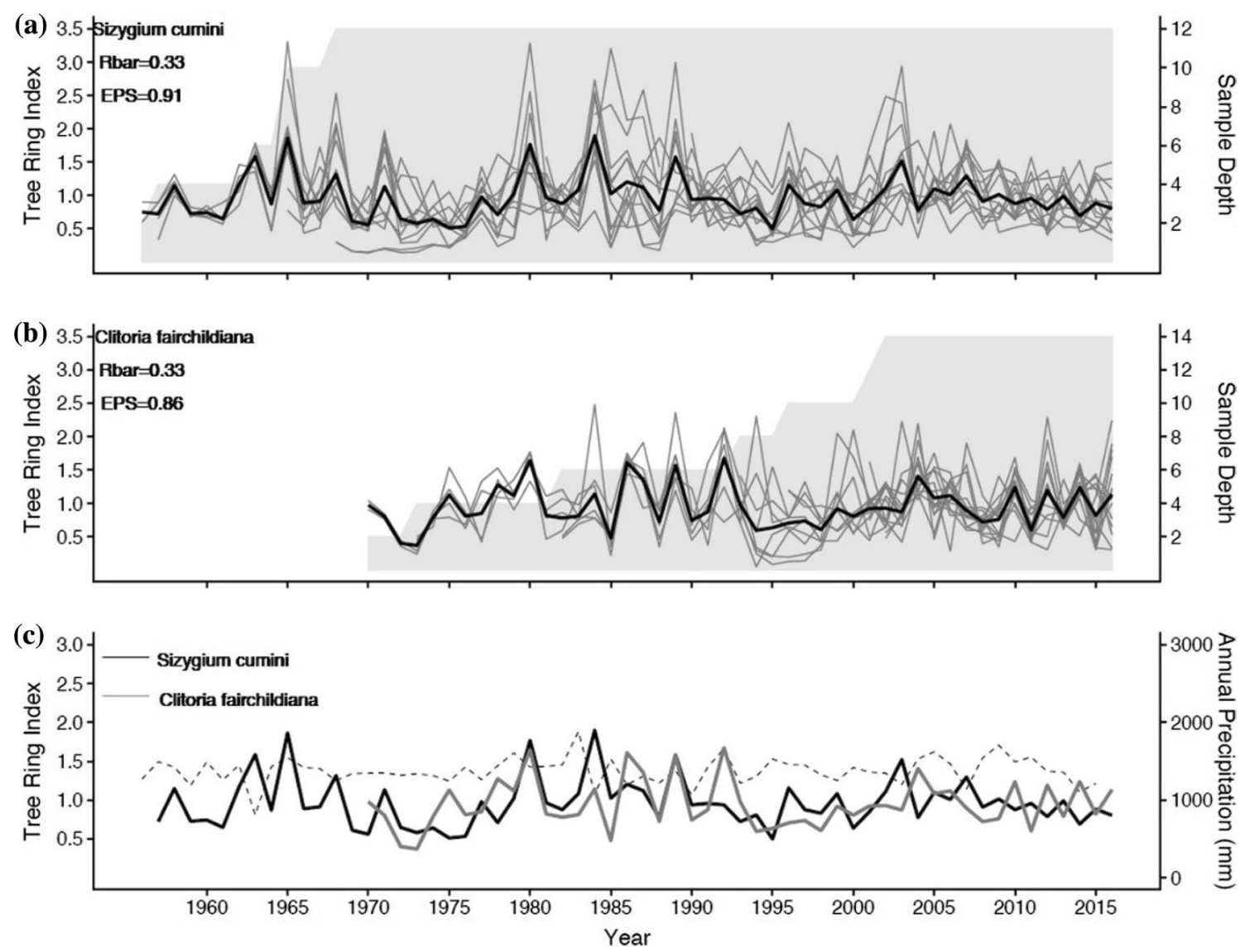

Fig. 4 Dated, detrended, and standardized radii (gray line) and mean index standard chronology (black line) of a Syzygium cumini (19562016) and b Clitoria fairchildiana (1970-2016); sample depths shown by shaded areas $(\mathbf{a}, \mathbf{b})$. Mean RBAR and EPS values obtained

their complete growth trajectories. Major release episodes dominated the forest disturbances observed within the analyzed $S$. cumini trees. Most release events occurred between 1970 and 2002 when trees experienced moderate to major disturbance events. More than one release episode was identified in the growth trajectories of four S. cumini and one C. fairchildiana trees. The oldest $S$. cumini germinated in 1941 while the majority of the individuals of this species germinated during the 1960s. Trees of $C$. fairchildiana show a more uneven age distribution.

\section{Discussion}

Distinct annual growth rings are reported for the first time for two invasive species, Syzygium cumini and Clitoria fairchildiana. Growth rings were successfully crossdated by standard dendrochronological techniques, and chronology statistics and internal coherence within and between trees support the annual nature of the growth rings in both species with the ARSTAN program are indicated; similarities of final index standard chronologies and $\mathbf{c}$ the total annual precipitation lagged 1 year $(t-1)$ shown at the bottom

(Stahle 1999). Previous studies have described poorly visible and erratic growth rings by $S$. cumini in western Kenya and the Western Ghats of India (Nath et al. 2012; David et al. 2014). However, tree-ring distinctiveness can be related to the environmental conditions where the trees are growing, (e.g., climate factors influencing local variability, stand and ecological parameters, and even different soil conditions). Working on larger cross-sectional samples allows a clearer view of the true growth ring boundaries, hence facilitating cross-dating between trees in tropical environments (Worbes 1985; Stahle et al. 1999; López et al. 2017; Barbosa et al. 2018). Artocarpus heterophyllus trees showed distinct growth rings but discontinuous and barely visible in some portions of the cross-sections and could not be crossdated with standard dendrochronological techniques.

The chronologies obtained of S. cumini and C. fairchildiana show that the growth of both species was positively influenced by rainfall of the previous rainy season. In fact, both species showed similar growth-climate responses, resulting in positive correlations between chronologies over 


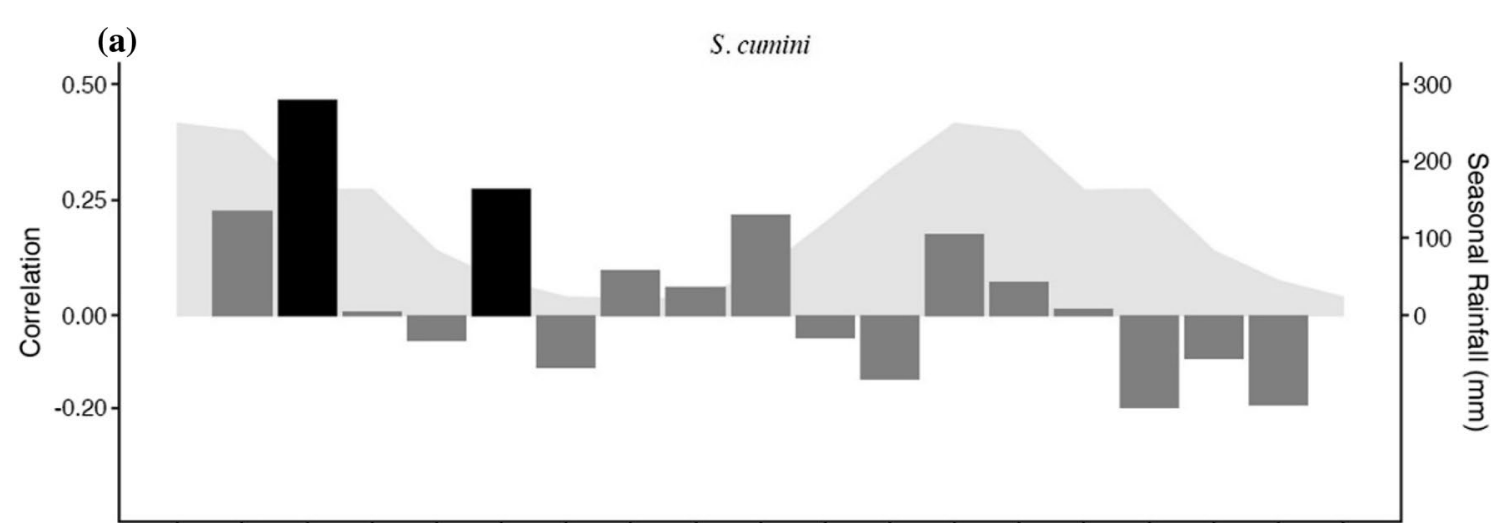

(b)

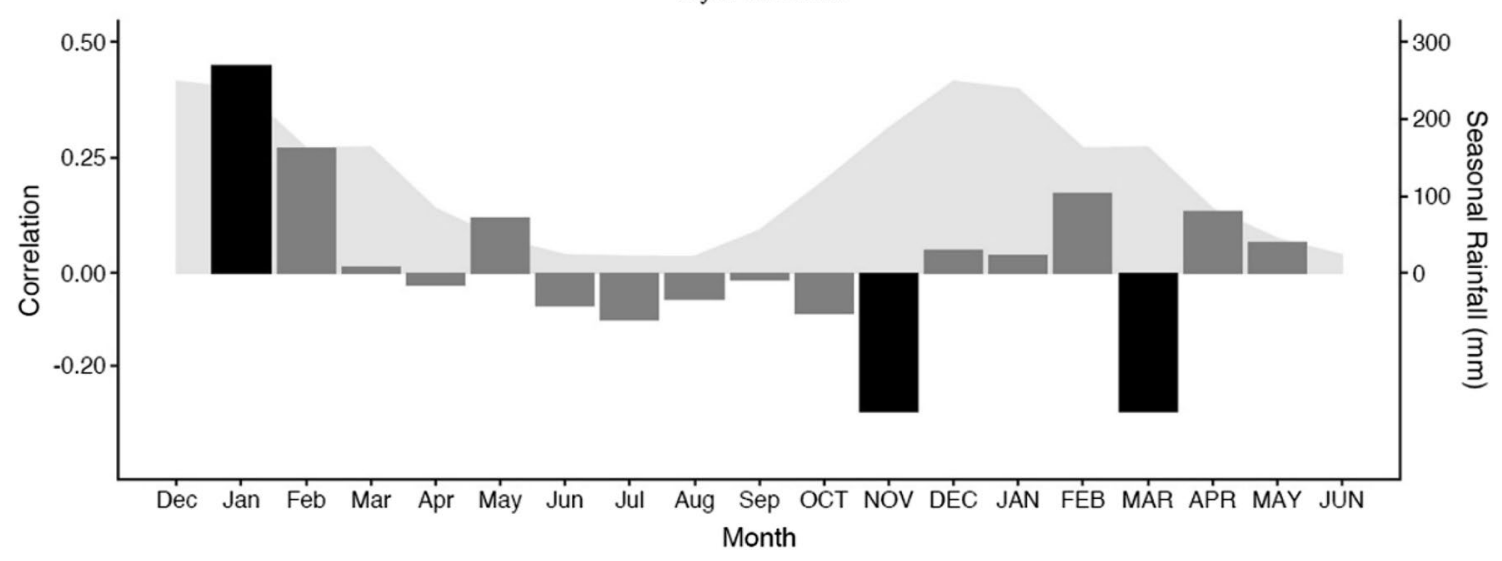

Fig. 5 Monthly values for CRU TS4.00 gridded precipitation correlated with standard chronologies of a Syzygium cumini from 1956 to 2016 and b Clitoria fairchildiana from 1970 to 2016 to identify monthly precipitation totals most important to radial growth of both species for a 19-month period, including previous rainy and dry sea- sons (lowercase letters) and the year concurrent with growth (uppercase letters). Filled black bars represent significant correlations. Gray area is seasonal precipitation (CRU TS4.00 $0.5^{\circ}$ gridded data set from 1956 to 2016)
Fig. 6 Cumulative ring-width increments for a S. cumini and b C. fairchildiana; Loessfunctions fitted to cumulative diameters (bold lines) represent smoothed conditional means (shaded areas are 95\% confidence intervals of the loessfunctions)
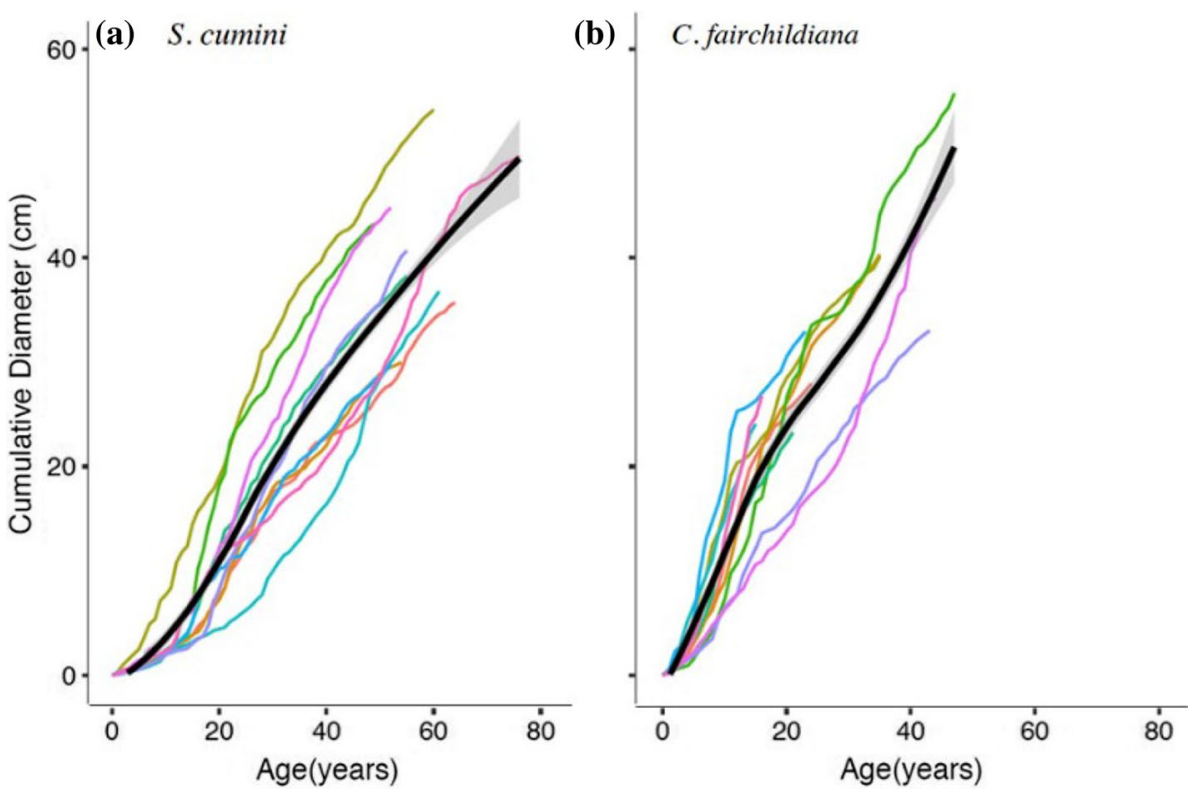
Fig. 7 Dates of release events per tree according to growth averaging method analysis of S. cumini and C. fairchildiana; moderate releases (black square) and major releases (black triangle)

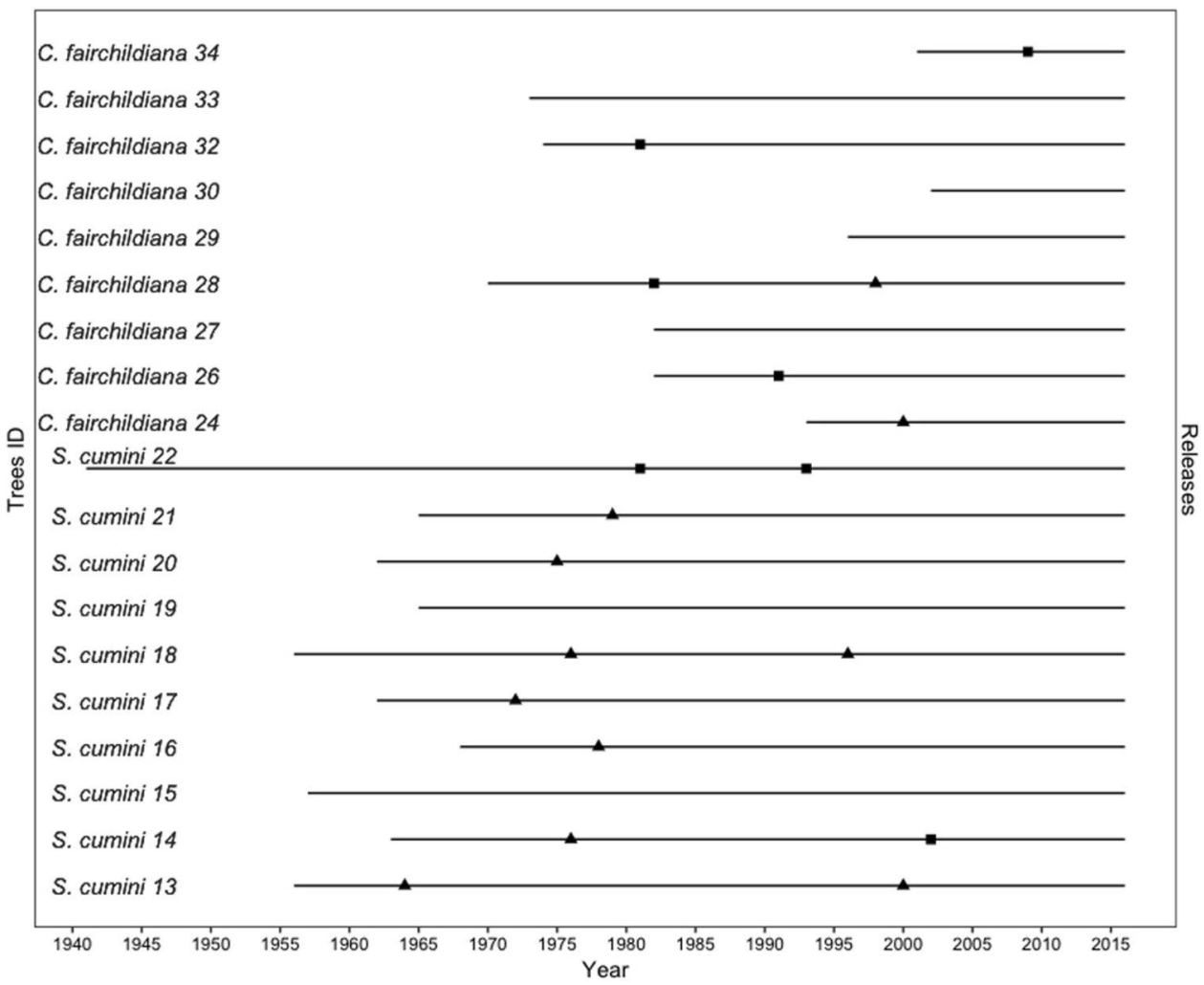

their lifespan. It is interesting that most native species in the Atlantic Forest environment show positive correlations between growth of the trees and precipitation of the current growing season (Latorraca et al. 2015; Souza et al. 2016; Fontana et al. 2018; Aragão et al. 2019). Moisture-sensitive tree species tend to grow and accumulate nutrients during the rainy season (Fritts 1976; Dünisch et al. 2003; Kunert et al. 2010) between September and April in the study area (Fig. 1d). However, a few native species have shown similar climate-growth relationships as $S$. cumini and C. fairchildiana (Pagotto et al. 2015; Aragão et al. 2019). One hypothesis is that they may have been producing and storing nutrients during the previous growing season which are likely used for secondary growth during the current growing season (Fritts 1976; Oliveira et al. 2009). It also may suggest an adaptive strategy to produce energy for flowering and fruiting during the current growing season, a period of high energy costs for plants (Lorenzi 1992; Woodhouse 1997; Lorenzi et al. 2003; Evert 2014), thus enhancing their successful establishment in a foreign environment. If they colonize a new area and become established over the native species, this growth strategy could be one of the reasons why they have successfully invaded the exotic environment.

Growth trajectory analyses show older and homogeneous age distribution among individuals of Syzygium cumini. The lower growth rates reported in this study confirm the behavior of S. cumini growing in Indian environments where trees may attain more than 100 years of age, suggesting this species is long-lived (Nath et al. 2012). A young, heterogeneous age distribution and relatively fast growth rates characterize the growth of $C$. fairchildiana. Their fast growth and high nitrogen fixation have been described in previous studies, suggesting it as a potential species for the recovery of degraded areas (Lorenzi 1992; Nobre et al. 2010; Costa et al. 2014). Both $S$. cumini and C. fairchildiana show similar average annual increments to those found for native species in the Atlantic Forest environment (Barbosa et al. 2018; Fontana et al. 2018) and do not show stabilized growth rates, which adds to the knowledge of the lifespan of these invasive non-native species.

Tree ring analyses showed that the oldest $S$. cumini individual dates from 1941, pointing to a successful establishment of the species, with the rest of the trees dating back to the 1960s. The oldest $C$. fairchildiana tree dates from 1970, showing most individuals are relatively young. It is possible that these dates do not represent the first introduction episodes of both species in the area and may be more likely to be natural recruitment. Historical records describe intense human activity such as cane sugar and cassava production and cattle breeding between the eighteenth and nineteenth century in the area where the Pedra Branca State Park is located (Drummond 1997). The area was expropriated by the federal government at the beginning of the twentieth century in order to recover the native vegetation and act as 
a protection of hydrological resources (Correa 1936; Costa 2002). Therefore, the trees in this study are regrowth of the first introductions and have successfully been colonizing the Atlantic Forest remnants for decades. A recent survey has recorded large populations for the alien species in this study, and raises concern by the administration of the Pedra Branca State Park (Fiotec 2016). This study shows how tree rings may be a reliable tool to access historical records and also provide key information about the status of ongoing species invasions in natural environments, one of the biggest threats to biodiversity conservation.

Moderate to major release episodes were detected in the growth of almost all the study trees of $S$. cumini and $C$. fairchildiana, primarily at the end of the twentieth century. Under natural and undisturbed environments, tree- growth variation is due to a combination of age-related trends, regional climate scale patterns, and stand exogenous and endogenous disturbances, and thus the effects of climate usually create a common signal between trees which allow them to be synchronized and dated (Fritts 1976; Cook 1990; Stokes and Smiley 1996). Local endogenous disturbances, in turns, create individual signals in each tree, and thus suppressed growth usually represents strong competition under a dense canopy (Tilman 1988; Cook 1990). Growth release episodes reflect the response of the trees to canopy openings, illustrating an important indicator of forest dynamics (Nowacki and Abrams 1997; Tanner et al. 2014; Abiyu et al. 2018).

Past records of forest disturbances can be accessed through the identification of the growth release events in each study tree and anthropogenic disturbances have been reported as the most important modifiers of forest dynamics and composition over the last century (McCann 1997; Bräuning et al. 2013; Abiyu et al. 2018). Despite the relatively long S. cumini chronology dating back to 1941, the first release episode was only detected in 1964, becoming more frequent after 1970, as well as an increased number of both non-native species in the area. This may represent an increasing effect of human-induced forest disturbance over the last 50 years, thus justifying the conservation status of the Pedra Branca State Park. Moreover, the detected growth release episodes show that $S$. cumini and $C$. fairchildiana have the potential to benefit from recent canopy openings and hence may be taking advantage to successfully replace native species.

This study presents information to help fill the gaps regarding the behavior of two non-native, invasive species in southeastern Brazil. Further research should also consider including tree-ring analyses with native species growing in the same forest fragment. This would provide interesting comparisons between climate-growth relationships and also improve analysis of growth trajectories, adding reliable contributions to the actual invasive status of the study area.

\section{Conclusions}

The Atlantic Forest of Brazil is one of the largest rainforests in South America, accounting for high biodiversity but is also a highly degraded environment due to the effects of human disturbances over many decades. The Brazilian government has implemented protected areas in an attempt to reduce habitat losses, and thus urban parks have been created to conserve the remaining vegetation. However, accidental or intentional introductions of alien species represents one of the greatest threats to the conservation of the native urban environments, and still, relatively little is known about the biological aspects of the invasions. Tree- ring analyses of Syzigium cumini and Clitoria fairchildiana provide interesting contributions on the ecological aspects of both species. Tree rings were successfully dated with standard dendrochronological techniques in both species. The climate- growth relationship shows a positive correlation between tree growth and precipitation of the previous growing season, which may represent a strategy to establish and invade the Atlantic Forest fragment. Growth trajectory analyses show slower growth rates for S. cumini and faster ones for C. fairchildiana. Growth release episodes identified for both species, mainly after the 1970s, suggest an increasing effect of human disturbances over the last 50 years. Future studies should consider a broader approach with a larger number of samples to improve the outcomes that could help clarify the biological invasions in the Atlantic Forest remnant in southeastern Brazil.

Acknowledgements The authors thank Fiocruz Campus Mata Atlântica for donating material and field support.

Open Access This article is licensed under a Creative Commons Attribution 4.0 International License, which permits use, sharing, adaptation, distribution and reproduction in any medium or format, as long as you give appropriate credit to the original author(s) and the source, provide a link to the Creative Commons licence, and indicate if changes were made. The images or other third party material in this article are included in the article's Creative Commons licence, unless indicated otherwise in a credit line to the material. If material is not included in the article's Creative Commons licence and your intended use is not permitted by statutory regulation or exceeds the permitted use, you will need to obtain permission directly from the copyright holder. To view a copy of this licence, visit http://creativecommons.org/licenses/by/4.0/.

\section{References}

Abiyu A, Mokria M, Gebrekirstos A, Bräuning A (2018) Tree-ring record in Ethiopian church forests reveals successive generation differences in growth rates and disturbance events. For Ecol Manag 409:835-844 
Altman J, Fibich P, Dolezal J, Aakala T (2014) TRADER: a package for tree ring analysis of disturbance events in R. Dendrochronologia 32:107-112

Aragão JRV, Groenendijk P, Lisi CS (2019) Dendrochronological potential of four neotropical dry-forest tree species: climategrowth correlations in northeast Brazil. Dendrochronologia 53:5-16

Atala F, Bandeira CM, Martins HF, Coimbra-Filho AF, Chaves CM, Tâmara R, Carauta JPP, Silveira EKP, Vianna MC (1966) Floresta da Tijuca. Centro de Conservação da Natureza, AGGS, Rio de Janeiro

Bandeira CM (1993) Parque Nacional da Tijuca. Markom Books, São Paulo

Barbosa UN (2016) Aspectos ecológicos e influência de Artocarpus heterophyllus Lam na estrutura do componente arbóreo de fragmento florestal urbano. Dissertation, Universidade Federal Rural de Pernambuco

Barbosa ACM, Pereira GA, Granato-Souza D, Santos RM, Fontes MAL (2018) Tree rings and growth trajectories of tree species from seasonally dry tropical forest. Aust J Bot 66:414-427

Braga FG, Bouzada MLM, Fabri RL, Matos MDO, Moreira FO, Scio E, Coimbra ES (2007) Antileishmanial and antifungal activity of plants used in traditional medicine in Brazil. J Ethnopharmacol 111:396-402

Brandes AFN, Albuquerque RP, Domingues GAF, Barros CF, Durigan G, Abreu RCR (2019) Dendroecology of Pinus elliottii Engelm. reveals waves of invasion in a neotropical savanna. Biol Invasions. https://doi.org/10.1007/s10530-019-02099-2

Bräuning A, Scharf A, Kretschmer W, Burchardt I (2013) Beyond dating: archeological wood as a source of information of environmental changes in High Asia. Trace 11:154-157

Brienen RJW, Zuidema PA (2005) Relating tree growth to rainfall in Bolivian rain forests: a test for six species using tree ring analysis. Oecologia 146(1):1-12

Brienen RJW, Zuidema PA (2007) Incorporating persistent tree growth differences increases estimates of tropical timber yield. Front Ecol Environ 5(6):302-306

Briffa KR (1995) Interpreting high-resolution proxy climate data: the example of dendroclimatology. In: Von Storch H, Navarra A et al (eds) Analysis of climate variability. Springer, Heidelberg

Callado CH, Neto SJS, Scarano FR, Costa CG (2001) Periodicity of growth rings in some flood- prone trees of the Atlantic rain forest in Rio de Janeiro, Brazil. Trees 15:492-497

Chaves CM, Martins HF, Carauta JPP, Lanna-Sobrinho JP, Vianna MC, Silva SAF (1967) Arboreto Carioca 3. Centro de Conservação da Natureza, Rio de Janeiro

Closset-Kopp D, Saguez R, Decocq G (2011) Differential growth patterns and fitness may explain contrasted performances of the invasive Prunus serotina in its exotic range. Biol Invasions 13:1341-1355

Conti VM, Iwamoto S, Almeida TM, Pereira TS (2008) Revisão dos limites do Jardim Botânico do Rio de Janeiro, Brasil. Rodriguésia 59:603-607

Cook ER (1985) A time series analysis approach to tree-ring standardization. Dissertation, University of Arizona, Tucson, p 171

Cook ER (1990) A conceptual linear aggregate model for tree rings. In: Cook ER, Krairiukstis LA (eds) Methods of dendrochronology. Kluwer Academic Publishers, Dordrecht, pp 98-104

Cook ER, Krusic PJ (2005) Program ARSTAN: a tree-ring standardization program based on detrending and autoregressive time series modeling, with interactive graphics. Tree-Ring Lab, Lamont Doherty Earth Observatory of Columbia University, Palisades. http://www.ldeo.columbia.edu. Accessed 9 Oct 2018

Cook ER, Pederson N (2011) Uncertainty, emergence, and statistics in dendrochronology. In: Hughes MK, Swetnam TW, Diaz HF (eds) Dendroclimatology, developments in paleoenvironmental research dendroclimatology: progress and prospects, vol 11. Springer, Berlin, pp 77-112

Correa AM (1936) O sertão carioca. Imprensa Nacional, Rio de Janeiro

Costa NMC (2002) Análise do Parque Estadual da Pedra Branca (RJ) por Geoprocessamento: Uma contribuição ao seu plano de manejo. Dissertation, Universidade Federal do Rio de Janeiro

Costa LG, Silva AG, Gomes DR (2014) Morfologia de frutos, sementes e plântulas, e anatomia das sementes de sombreiro (Clitoria fairchildiana). Amazon J Agric Environ Sci 57:414-421

Crane JH, Balerdi CF, Campbell RJ (2002) The Jackfruit (Artocarpus heterophyllus Lam.) in Florida. University of Florida IFAS Extension. Fact Sheet HS-882

Cunha AA, Vieira MV, Grelle CE (2006) Preliminary observations on habitat, support use and diet in two non-native primates in an urban Atlantic Forest fragment: the capuchin monkey (Cebus sp.) and the commom marmoset (Callithrix jacchus) in the Tijuca forest, Rio de Janeiro. Urban Ecosyst 9:351-359

David ET, Chhin S, Skole D (2014) Dendrochronological potential and productivity of tropical tree species in western Kenya. Tree-Ring Res 70:119-135

Dean W (2002) A ferro e fogo: a história e a devastação da Mata Atlântica brasileira. Companhia das Letras, São Paulo

Donadio LC (2007) Dicionário das frutas. UNESP, Jaboticabal

Douglass AE (1941) Crossdating in dendrochronology. J For 39:825-831

Drummond JA (1997) Devastação e preservação ambiental: os parques nacionais do Estado do Rio de Janeiro. EDUFF, Niterói

Dünisch O, Montóia VR, Bauch J (2003) Dendroecological investigations on Swietenia macrophylla King and Cedrela odorata L. (Meliaceae) in the central Amazon. Trees 17(3):244-250

Evert RF (2014) Raven biology of plants, 8th edn. Guanabara Koogan, Rio de Janeiro

Ferrão JEM (1993) A aventura das plantas e osdescobrimentos portugueses, 2nd edn. Instituto de Investigação Cientifica Tropical, Lisboa

Fiocruz Fundação Oswaldo Cruz (2009) Plano diretor do campus Fiocruz da mata atlântica Jacarepaguá, Rio de Janeiro: Programa de implantação do campus Fiocruz da mata atlântica (PICFMA). Fiocruz, Rio de Janeiro

Fiotec Fundação para Desenvolvimento Científico e Tecnológico em Saúde-BNDES Mata Atlântica (2016) Relatório Final: Restauração ecológica de 344 hectares de Mata Atlântica com espécies nativas; Reativação do Horto-Escola do Campus Fiocruz da Mata Atlântica

Fontana C, Pérez-de-Lis G, Nabais C, Lousada JLPC, Olmedo GM, Botosso PC, Oliveira JM (2018) Climatic signal in growth-rings of Copaifera lucens: an endemic species of a Brazilian Atlantic Forest hotspot, southeastern Brazil. Dendrochronologia 50:23-32

Forzza RC, Baumgratz JF, Bicudo CE, Canhos DA, Carvalho AA, Coelho MA, Costa AF, Costa DP, Hopkins MG, Leitman PM, Lohmann LG, Lughadha EN, Maia LC, Martinelli G, Menezes M, Morim MP, Peixoto AL, Pirani JR, Prado J, Queiroz LP, Souza S, Souza VC, Stehmann JR, Sylvestre LS, Walter BMT, Zappi DC (2012) New Brazilian floristic list highlights conservation challenges. Bioscience 62:39-45

Fritts HC (1976) Tree rings and climate. Academic Press, London

Gaertner M, Wilson JR, Cadotte MW, MacIvor JS, Zenni RD, Richardson DM (2017) Non-native species in urban environments: patterns, processes, impacts and challenges. Biol Invasions 19:3461-3469

Gurgel JLA, Soubihe Sobrinho J (1951) Poliembrionia em mirtáceas frutíferas. Bragantia 11(6):141-163

Harris I, Jones PD, Osborn TJ, Lister DH (2014) Updated high-resolution grids of monthly climatic observations-the CRU TS3.10 dataset. Int J Climatol 34(3):623-642 
Holmes RL (1983) Computer-assisted quality control in tree ring dating and measurement. Tree-Ring Bull 43:69-78

IAWA Committee (1989) IAWA list of microscopic features for hardwood identification. IAWA Bull 10:219-232

INEA (2015) Atlas of protected areas in Rio de Janeiro state. Metalivros, Rio de Janeiro

Kasson MT, Davis MD, Davis DD (2013) The invasive Ailanthus altissima in Pennsylvania: a case study elucidating species introduction, migration, invasion, and growth patterns in the northeastern US. Northeast Nat 20:1-60

Kunert N, Schwendenmann L, Hölscher D (2010) Seasonal dynamics of tree sap flux and water use in nine species in Panamanian forest plantations. Agric For Meteorol 150:411-419

Latorraca JVF, Souza MT, Silva LDSAB, Ramos LMA (2015) Dendrochronology of Schizolobium parahyba (Vell.) S. F. Blake trees from Tinguá biological reserve-RJ. Rev Árvore 39:385-394

Lima LA, Siani AC, Brito FA, Sampaio ALF, Henriques MDGMO, Riehl CADS (2007) Correlation of anti-inflammatory activity with phenolic content in the leaves of Syzygium cumini (L.) skeels (Myrtaceae). Quim Nova 30:860-864

Lisi CS, Tomazello Filho M, Botosso PC, Roig FA, Maria VRB, Ferreira-Fedele L, Voigt ARA (2008) Tree-ring formation, radial increment periodicity, and phenology of tree species from a seasonal semi-deciduous forest in Southeast Brazil. IAWA J 29:189-207

López L, Stahle D, Villalba R, Torbenson M, Feng S, Cook E (2017) Tree-ring reconstructed rainfall over the southern Amazon Basin. Geophys Res Lett 44:7410-7418

Lorenzi H (1992) Árvores brasileiras: manual de identificação e cultivo de plantas arbóreas nativas do Brasil. Plantarum, Nova Odessa

Lorenzi H, Souza HM, Torres MAV, Bacher LB (2003) Arvores exóticas no Brasil: madeireiras, ornamentais e aromáticas. Instituto Plantarum, Nova Odessa

McCann JC (1997) The plow and the forest: narratives of deforestation in Ethiopia, 1840-1992. Environ Hist 2:138-159

Mérian P, Pierrat JC, Lebourgeois F (2013) Effect of sampling effort on the regional chronology statistics and climate-growth relationships estimation. Dendrochronologia 31:58-67

Myers N, Mittermeier RA, Mittermeier CG, Fonseca GAB, Kent J (2000) Biodiversity hotspots for conservation priorities. Nature 403:853-858

Nath CD, Boura A, De Franceschi D, Pélissier R (2012) Assessing the utility of direct and indirect methods for estimating tropical tree age in the Western Ghats, India. Trees 26(3):1017-1029

Nobre CP, Ferraz Júnior ASL, Goto BT, Berbara RLL, Nogueira MDC (2010) Fungos micorrízicos arbusculares em sistema de aléias no Estado do Maranhão, Brasil. Acta Amazon 40(4):641-646

Nogueira FC Jr, Pagotto MA, Aragão JRV, Roig FA, Ribeiro AS, Lisi CS (2019) The hydrological performance of Prosopis juliflora (Sw.) growth as an invasive alien tree species in the semiarid tropics of northeastern Brazil. Biol Invasions. https://doi.org/10.1007/ s10530-019-01994-y

Nowacki GJ, Abrams MD (1997) Radial-growth averaging criteria for reconstructing disturbance histories from presettlement-origin oaks. Ecol Monogr 67:225-249

Nuñez MA, Paritsis J (2018) How are monospecific stands of invasive trees formed? Spatio-temporal evidence from Douglas fir invasions. AoB Plants 10:ply041. https://doi.org/10.1093/aobpl a/ply041

Oliveira JM, Santarosa E, Pillar VD, Roig FA (2009) Seasonal cambium activity in the subtropical rain forest tree Araucaria angustifolia. Trees 23:107-115
Pagotto MA, Roig FA, Ribeiro AS, Lisi CS (2015) Influence of regional rainfall and Atlantic sea surface temperature on tree-ring growth of Poincianella pyramidalis, semiarid forest from Brazil. Dendrochronologia 35:14-23

R Core Team (2018) R: A language and environment for statistical computing. R Foundation for Statistical Computing, Vienna

Rinntech (2017) LINTAB: precision-for every single tree ring. Heidelberg, Germany. http://www.rinntech.de/content/view/16/47/ lang,english/index.html. Accessed 9 Oct 2018

Sampaio AB, Schmidt IB (2014) Espécies exóticas invasoras em Unidades de Conservação federais do Brasil. Biodivers Bras 2:32-49

Santos AR, Bergallo HG, Rocha CFD (2008) Paisagem urbana alienígena. Ciência Hoje 41:68-70

Schöngart J (2008) Growth-oriented logging (GOL): a new concept towards sustainable forest management in Central Amazonian várzea floodplains. For Ecol Manag 256:46-58

Schöngart J, Gribel R, Ferreira da Fonseca-Junior S, Haugaasen T (2015) Age and growth patterns of Brazil nut trees (Bertholletia excelsa Bonpl.) in Amazonia, Brazil. Biotropica 47(5):550-558

Siani AC, Sampaio ALF, Souza MC, Henriques MGMO, Ramos MFS (2000) Óleos Essenciais: potencial antiinflamatório. Biotecnol Ciênc Desenvolv 16:38-43

Soares GLG, Scalon VR, Pereira TODO, Vieira DDA (2002) Potencial alelopático do extrato aquoso de folhas de algumas leguminosas arbóreas brasileiras. Floresta e Ambiente 9:119-126

Souza BT, Estrada GCD, Soares MLG, Callado CH (2016) Occurrence of annual growth rings in Rhizophora mangle in a region with low climate seasonality. An Acad Bras Ciênc 88:517-525

Stahle DW (1999) Useful strategies for the development of tropical tree-ringchronologies. IAWA J 20(3):249-253

Stahle DW, Mushove PT, Cleaveland MK, Roig FA, Haynes GA (1999) Management implications of annual growth rings in Pterocarpus angolensis from Zimbabwe. For Ecol Manag 124:217-229

Stokes MA, Smiley TL (1996) An introduction to tree-ring dating. University of Arizona Press, Tucson

Tabarelli M, Pinto LP, Silva JM, Hirota M, Bede L (2005) Challenges and opportunities for biodiversity conservation in the Brazilian Atlantic Forest. Conserv Biol 19(3):695-700

Tanner EVJ, Rodriguez-Sanchez F, Healey JR, Holdaway RJ, Bellingham PJ (2014) Long-term hurricane damage effects on tropical forest tree growth and mortality. Ecology 95:2974-2983

Tilman D (1988) Plant strategies and the dynamics and structure of plant communities. Princeton University Press, Princeton

Vizzotto M, Fetter MR (2009) Jambolão: o poderoso antioxidante. Embrapa, Brasilia

Wigley TML, Briffa KR, Jones PD (1984) On the average value of correlated time series with applications in dendrochronology and hydrometeorology. J Climatol Appl Meteorol 23(2):201-213

Woodhouse CA (1997) Tree-ring reconstructions of circulation indices. Climate Res 8:117-127

Worbes M (1985) Structural and other adaptations to long-term flooding by trees in Central Amazonia. Amazoniana 9:459-484

Zang C, Biondi F (2015) Treeclim: an R package for the numerical calibration of proxy-climate relationships. Ecography 38(4):431-436

Zenni RD, Ziller SR (2011) An overview of invasive plants in Brazil. Braz J Bot 34(3):431-446

Publisher's Note Springer Nature remains neutral with regard to jurisdictional claims in published maps and institutional affiliations. 